\title{
Borna Disease Virus Antibody and RNA from Peripheral Blood Mononuclear Cells of Race Horses and Jockeys in Korea
}

\author{
Jin-Won Song ${ }^{1,3}$, Kyoung-Sae $\mathrm{Na}^{2}$, Seong-Ho $\mathrm{Tae}^{2}$ and Yong-Ku Kim ${ }^{2,3} \bowtie$ \\ 1Departments of Microbiology and ${ }^{2} P$ sychiatry, College of Medicine, Korea University, Seoul, Korea \\ ${ }^{3}$ Division of Brain Korea 21 Biomedical Science, Korea University, Seoul, Korea
}

\begin{abstract}
Objective During the last two decades, Borna disease virus (BDV) has received much attention as a possible zoonotic agent, particularly as a cause of psychiatric disease. Although several studies have shown that BDV is present in Asia, BDV has not been detected in Korea. This study was designed to further investigate the presence of BDV infection in Korea.

Methods Blood samples were taken from 39 race horses and 48 jockeys. Antibody to BDV was detected by indirect immunofluorescence antibody test and RNA of BDV by real time reverse transcriptase PCR (rRT-PCR).

Results No evidence of BDV was detected in either the horses or the jockeys group.

Conclusion Our results suggest that BDV infection may not be endemic in Korea. Further studies with novel diagnostic tools are required to clarify the prevalence of BDV infection in Korea.

Psychiatry Investig 2011;8:58-60
\end{abstract}

Key Words Borna disease virus, Horses, Jockeys, Real time RT-P.

\section{INTRODUCTION}

Borna disease virus (BDV) is an enveloped, negative-stranded, and highly neurotropic RNA virus. It mainly infects the limbic system, hippocampus, and cerebellum. Animals infected with BDV show various symptoms such as aggression, ataxia, hyperexcitability, and stereotypic behaviour reminiscent of psychiatric symptoms in human. Due to those similarities, BDV has been considered to be a possible zoonotic agent that may contribute to psychiatric disease. ${ }^{1}$

Although various warm-blooded animals could be infected with BDV, horses have been known to be the main natural hosts. ${ }^{2}$ BDV infection causes delayed immunopathology and most animals infected with BDV are asymptomatic. ${ }^{3}$ Inoue et al. has revealed that 18 out of 35 (51.4\%) horses infected with BDV could

Received: June 12, 2010 Revised: September 30, 2010

Accepted: October 27, $2010 \quad$ Available online: November 27, 2010

$\square$ Correspondence: Yong-Ku Kim, MD, PhD

Department of Psychiatry, College of Medicine, Korea University, Ansan Hospital, 516 Gojan-dong, Ansan 425-020, Korea

Tel: +82-31-412-5140, Fax: +82-31-412-5144, E-mail: yongku@korea.ac.kr

@ This is an Open Access article distributed under the terms of the Creative Commons Attribution Non-Commercial License (http://creativecommons.org/licenses/by$\mathrm{nc} / 3.0$ ) which permits unrestricted non-commercial use, distribution, and reproduction in any medium, provided the original work is properly cited. be seropositive for BDV without any clinical symptoms for 4 consecutive years. ${ }^{4}$

Initially, BDV infection has been known to be endemic mainly in central Europe such as Germany and Austria. ${ }^{5}$ However, now it has been reported that horses infected with BDV could be found in Asia. ${ }^{6-11}$ The prevalence of BDV antibodies or RNA in asymptomatic horses in Asia is as follows: $16.7-29.8 \%$ in Japan, ${ }^{4,12,13} 20 \%$ in China, ${ }^{7}$ and $23.5-41.2 \%$ in Iran. ${ }^{6}$ There have been also evidences that people living near animals could be infected with BDV. ${ }^{12,14}$

Despite the growing evidences of the BDV infection in Asia, there has been no report on the BDV prevalence in animals in Korea. Previously, we examined BDV RNA in race horses and jockeys riding the horses using by one-tube reverse transcriptase Polymerase Chain Reaction (PCR) (RT-PCR) and nested RT-PCR, but failed to detect BDV RNA in horses and jockeys. ${ }^{15}$ Thus in this study, we aimed to investigate BDV markers by other methods, real time RT-PCR (rRT-PCR). Considering some evidences indicating discrepancies between serologic study and RT-PCR result, ${ }^{16,17}$ we used both indirect immunofluorescence antibody (IFA) test and rRT-PCR to compare the results of two methods. We also tried to examine the correlation between the prevalence of BDV in the horses and jockeys. 


\section{METHODS}

\section{Subjects}

Thirty-nine race horses (nine were thoroughbred, 30 were cross-bred) were included in the study. Twenty-three horses were female, and 16 male. The mean age of the horses was 3.1 years ( $\mathrm{SD}=3.3$, range: $1-15$ years). Clinical and neurological examinations of the horses were performed by a veterinarian. All horses were in a healthy condition. The study protocol was approved by the Ethics Committee of Korea University.

Forty-eight jockeys were also included. Their mean age was 31.2 years ( $\mathrm{SD}=5.5$, range: $22-40$ years), and their mean duration of contact with horses was 11.2 years $(\mathrm{SD}=5.8$, range: $1-22$ years). None had any psychiatric or medical illness, as assessed by means of clinical interviews and physical examinations. Three jockeys had a current familial history of psychiatric illness (2 depression, 1 alcoholism). All the subjects in this study were included in our previous study. ${ }^{15}$ Informed consent was obtained from the jockeys and the Seoul Horse Race Association.

\section{Preparation of peripheral blood mononuclear cells}

A sample of fasting blood $(20 \mathrm{~mL})$ was drawn from each subject. Preparation of peripheral blood mononuclear cells (PBMCs) were isolated from anticoagulant(lithium heparin)-treated blood by Ficoll-hypaque gradient centrifugation. Total RNA was extracted from PBMCs using RNAzol (Gibco/BRL, Gaithersburg, MD).

\section{Serological detection of BDV infection with indirect immunofluorescent antibody test}

Indirect immunofluorescent antibody (IFA) test was conducted according to the method previously described. ${ }^{18}$ The Madine Darby canine kidney (MDCK) cell line and MDCK cell line persistently infected with BDV (MDCK-BDV) ${ }^{19}$ cultured for 5 days with Dulbecco's Modified Eagle Medium (DMEM) (Gibco/BRL, Germany) supplemented with 10\% fetal bovine serum (FBS) (Gibco/BRL, Germany), were trypsinized, suspended in phosphate buffered saline (PBS), spotted onto Teflon-coated 10-well slides, and air-dried in room temperature. Cells on the 10-well antigen slide were fixed with anhydrous acetone at $-20^{\circ} \mathrm{C}$ for 7 minutes and dried. Human and horse serum samples diluted in PBS as 1:32 were treated to MDCK cell and MDCK-BDV cell on antigen slide and the slide was incubated in humidity chamber at $37^{\circ} \mathrm{C}$ for 30 minutes. After three washes with PBS, Fluorescein isothiocyanate conjugated antihuman immunoglobulin goat IgG (MP Biomedicals Inc., USA) was added to each well and the slide was incubated in humidity chamber at $37^{\circ} \mathrm{C}$ for 30 minutes. The slides were mounted with glycine-buffered glycerol under cover slips and examined for characteristic cytoplasmic fluorescent pattern with a fluo- rescence microscope.

\section{Genetic detection of viral genomic RNA with real-time reverse transcription-polymerase chain reaction}

Real-time quantitative RT-PCR for nucleoprotein (p40) and phosphoprotein (p24) genes of BDV was performed to detect RNA genome of BDV in PBMCs. The primers and probes described in previously study were used for rRT-PCR. ${ }^{20}$ For the construction of the quantitative standard, p40 and p24 genes were amplified by RT-PCR and cloned to pGEM-T Easy vector system (Promega, USA). Cloned p40 and p24 genes were transcribed to RNA using the MEGAscript T7 transcription kit (Ambion Inc., USA) in accordance with the manufacturer's instructions. The amounts of p40 and p24 RNA transcribed using by in vitro transcription system were measured by optical density. p40 and p24 RNA were used for the reverse transcription reaction template from $1 \times 1,010$ copies $/ \mu \mathrm{L}$ to $1 \times 103$ copies $/ \mu \mathrm{L}$ diluted by 10 -fold dilution method. After the reverse transcription reaction, the Taqman Universal PCR Master Mix (applied Biosystems, USA) was used for the real-time PCR reaction as recommended by manufacturer's instruction. The real-time PCR reaction mixtures were incubated for 10 minutes at $95^{\circ} \mathrm{C} ; 40$ cycles of amplification were performed using ABI PRISM 7000 Sequence Detection System (Applied Biosystems, USA). Each cycle consisted of a denaturation step $\left(15\right.$ seconds at $\left.95^{\circ} \mathrm{C}\right)$ and an annealing-elongation step $\left(1\right.$ minute at $\left.60^{\circ} \mathrm{C}\right)$. Threshold cycle $(\mathrm{Ct})$ values, i.e., the number of cycles for fluorescence to reach to clearly detectable levels, over 40 were regarded as negative.

\section{Statistical analysis}

To analyze demographic data, two-tailed t-test was used for continuous covariates. For discrete covariates, chi-square test was used. The null hypothesis was rejected at $\mathrm{p}<0.05$. The statistical package used for the analysis was Statistical Package for the Social Sciences 11.01.

\section{RESULTS}

The p 24 and p40 RNA were not detected by rRT-PCR in the horses and jockeys. Indirect IFA was conducted for the serological detection of BDV antibodies. No BDV antibody was detected by IFA in the horses and jockeys.

\section{DISCUSSION}

We failed to demonstrate BDV RNA and antibody from PBMCs in race horses and jockeys. This result is contrary to several previous studies demonstrating BDV infection in healthy horses in Asia. In Japan, Nakamura et al. ${ }^{13}$ found that 17 out 
of $57(29.8 \%)$ healthy horses were RNA positive and Takahashi et al. ${ }^{12}$ reported that 7 out of 54 (12.9\%) healthy thoroughbred race horses and 4 out of 57 (7.0\%) blood donors living near those horses were RNA positive, while in Iran, Bahmani et al. ${ }^{6}$ reported an RNA positive rate of $23.6 \%$ in healthy race horses (17 out of 72 ).

Two main reasons might account for the difference between this study and previous Asian reports of BDV occurrence. The first possibility is the difference in diagnostic tools. All of the above mentioned studies detected BDV RNA by nested RTPCR, which is highly sensitive to contamination, indeed Durrwald et al. ${ }^{21}$ suggested that most of the BDV positive reported using nested RT-PCR might actually be the result of inadvertent sample contamination. In this study we used rRT-PCR to detect BDV RNA, which has no carry-over contamination risk. ${ }^{22}$ The second possibility is that, in contrast to other areas in Asia, Korea may not be a BDV-endemic area. This agrees with our previous studies which have failed to detect BDV antibodies and RNA in psychiatric patients in $\mathrm{Korea}^{23}$ and Japan. ${ }^{24}$ We also used lithium heparin-treated blood for preparation of total RNA from PBMCs. However, ethylenediaminetetraacetic acid is better than heparin as anticoagulant because heparin inhibits the reaction of RT-PCR.

Limitations to this study include its small sample size and restricted region. To accurately determine the BDV prevalence in Korea, large-scaled study should be performed in several different regions.

\section{Acknowledgments}

Funding for this study was provided by a grant from the Korea Health 21 R\&D Project, Ministry of Health and Welfare, Republic of Korea (A040042).

\section{REFERENCES}

1. Taieb O, Baleyte JM, Mazet P, Fillet AM. Borna disease virus and psychiatry. Eur Psychiatry 2001;16:3-10.

2. Richt JA, Rott R. Borna disease virus: a mystery as an emerging zoonotic pathogen. Vet J 2001;161:24-40.

3. Planz O, Pleschka S, Wolff T. Borna disease virus: a unique pathogen and its interaction with intracellular signalling pathways. Cell Microbiol 2009;11:872-879.

4. Inoue Y, Yamaguchi K, Sawada T, Rivero JC, Horii Y. Demonstration of continuously seropositive population against Borna disease virus in Misaki feral horses, a Japanese strain: a four-year follow-up study from 1998 to 2001. J Vet Med Sci 2002;64:445-448.

5. Ludwig H, Bode L. Borna disease virus: new aspects on infection, disease, diagnosis and epidemiology. Rev Sci Tech 2000;19:259-288.

6. Bahmani MK, Nowrouzian I, Nakaya T, Nakamura Y, Hagiwara K, Takahashi $\mathrm{H}$, et al. Varied prevalence of Borna disease virus infection in Ar- abic, thoroughbred and their cross-bred horses in Iran. Virus Res 1996;45: 1-13.

7. Hagiwara K, Asakawa M, Liao L, Jiang W, Yan S, Chai J, et al. Seroprevalence of Borna disease virus in domestic animals in Xinjiang, China. Vet Microbiol 2001;80:383-389.

8. Nakamura Y, Asahi S, Nakaya T, Bahmani MK, Saitoh S, Yasui K, et al. Demonstration of borna disease virus RNA in peripheral blood mononuclear cells derived from domestic cats in Japan. J Clin Microbiol 1996; 34:188-191.

9. Nakamura Y, Watanabe M, Kamitani W, Taniyama H, Nakaya T, Nishimura $\mathrm{Y}$, et al. High prevalence of Borna disease virus in domestic cats with neurological disorders in Japan. Vet Microbiol 1999;70:153-169.

10. Hagiwara K, Kamitani W, Takamura S, Taniyama H, Nakaya T, Tanaka $\mathrm{H}$, et al. Detection of Borna disease virus in a pregnant mare and her fetus. Vet Microbiol 2000;72:207-216.

11. Yilmaz H, Helps CR, Turan N, Uysal A, Harbour DA. Detection of antibodies to Borna disease virus (BDV) in Turkish horse sera using recombinant p40. Brief report. Arch Virol 2002;147:429-435.

12. Takahashi H, Nakaya T, Nakamura Y, Asahi S, Onishi Y, Ikebuchi K, et al. Higher prevalence of Borna disease virus infection in blood donors living near thoroughbred horse farms. J Med Virol 1997;52:330-335.

13. Nakamura Y, Kishi M, Nakaya T, Asahi S, Tanaka H, Sentsui H, et al. Demonstration of Borna disease virus RNA in peripheral blood mononuclear cells from healthy horses in Japan. Vaccine 1995;13:1076-1079.

14. Thomas DR, Chalmers RM, Crook B, Stagg S, Thomas HV, Lewis G, et al. Borna disease virus and mental health: a cross-sectional study. QJM 2005;98:247-254.

15. Kim YK, Noh KB, Han CS, Moon JY, Yoon DK, Song KJ, et al. No Borna disease virus-specific RNA detected in blood of race horses and jockeys. Acta Neuropsychiatr 2006;18:177-180.

16. Kamhieh S, Hodgson J, Bode L, Ludwig H, Ward C Flower RL. No evidence of endemic Borna disease virus infection in Australian horses in contrast with endemic infection in other continents. Arch Virol 2006;151: 709-719.

17. Wolff T, Heins G, Pauli G, Burger R Kurth R. Failure to detect Borna disease virus antigen and RNA in human blood. J Clin Virol 2006;36: 309-311.

18. Rott R, Herzog S, Fleischer B, Winokur A, Amsterdam J, Dyson W, et al. Detection of serum antibodies to Borna disease virus in patients with psychiatric disorders. Science 1985;228:755-756.

19. Herzog S, Rott R. Replication of Borna disease virus in cell cultures. Med Microbiol Immunol 1980;168:153-158.

20. Watanabe M, Lee BJ, Kamitani W, Kobayashi T, Taniyama H, Tomonaga K, et al. Neurological diseases and viral dynamics in the brains of neonatally borna disease virus-infected gerbils. Virology 2001;282:65-76.

21. Dürrwald R, Kolodziejek J, Herzog S, Nowotny N. Meta-analysis of putative human bornavirus sequences fails to provide evidence implicating Borna disease virus in mental illness. Rev Med Virol 2007;17:181-203.

22. Wensman JJ, Thorén P, Hakhverdyan M, Belák S, Berg M. Development of a real-time RT-PCR assay for improved detection of Borna disease virus. J Virol Methods 2007;143:1-10.

23. Na KS, Tae SH, Song JW, Kim YK. Failure to detect borna disease virus antibody and RNA from peripheral blood mononuclear cells of psychiatric patients. Psychiatry Investig 2009;6:306-312.

24. Nishino Y, Funaba M, Fukushima R, Mizutani T, Kimura T, lizuka R, et al. Borna disease virus infection in domestic cats: evaluation by RNA and antibody detection. J Vet Med Sci 1999;61:1167-1170. 